\title{
ANALYSIS OF PHYSICAL EDUCATION TEACHER EDUCATION IN ALBANIA AND BULGARIA
}

\author{
Florian Muca, Eleonora Mileva \\ National Sports Academy "Vassil Levski", Sofia, Bulgaria
}

\begin{abstract}
The study was aimed at the comparative analysis of physical education teacher education (PETE) in Albania and Bulgaria. The object of the study was the system of professional preparation and qualification of physical education teachers in both countries. The main method of comparative analysis was the analysis of normative documents and learning programmes in Albania and Bulgaria. Similarities in the functioning of PETE system in the two Balkan countries were found. New regulations and documents for teachers' education were adopted. At the same time, there were differences in the preparation of physical education teachers in both countries on the different levels of professional qualification. Some specific characteristics of each PETE system have been outlined.
\end{abstract}

Key words: training, qualification, learning programmes, educational system, regulation

\section{INTRODUCTION}

The development of education in Bulgaria and Albania is an integral part of the social, cultural and political development in the countries (https://lex. bg/bg/laws/ldoc/2136641509; Education Policy Review Albania, 2017). The educational policy in both countries is directed to an alignment with the European requirements at all levels of the educational systems (Mileva, 2012; Mileva et al, 2017; Klincarov et al., 2017).

Bulgaria and Albania have traditions in physical education teacher education (PETE). At the same time both countries are undergoing significant educational reforms. New strategies and regulations are implemented. These reforms affect the educational policy and professional development of the teaching staff in the perspective of the European integration.

The comparative study of PETE in Bulgaria and Albania will be helpful to outline the similarities and the differences in the functioning of both systems. We suppose that the current and future analysis will improve the communication between educational stakeholders and institutions in Bulgaria and Albania and will enhance the collaboration in the area of PETE.

\section{METHODOLOGY}

The aim of the study was to make a comparative analysis of physical education teacher education (PETE) in Albania and Bulgaria. The object of the study was the system of professional preparation and qualification of physical education teachers in both countries.
The main method of comparative analysis was the analysis of normative documents and learning programmes in Albania and Bulgaria. The following criteria were applied: 1) regulations and laws in educational sphere; 2) status of PE subject in the educational system and teaching hours; 3 ) pre-service training of $\mathrm{PE}$ teachers; 4) in-service training of PE teachers.

It was significant to study and compare similarities and differences including general and specific characteristics between both PETE systems, also to investigate to what extent the elements of each educational system aligned with the European standards and requirements.

\section{RESULTS}

In 2016 the new Law for Pre-school and School education was adopted in Bulgaria (www.mon.bg), Regulation № 12 of 01.09.2016 on the status and professional development of teachers, principals and other pedagogical specialists. The new version of this Regulation was adopted in July 2019 (www. mon.bg). It specifies the levels of teachers' education and teachers' career development.

The quality of school physical education (PE) in the country is connected with the State Educational Standards (new standards since 2015) for learning content, evaluation system, professional qualification of $\mathrm{PE}$ teachers and for the whole provision of PE at school.

A state educational standard for general education preparation is a set of requirements for the learning outcomes of each general school subject and defines competencies - knowledge, skills and attitudes 
that are expected as the learning outcomes of the learning curriculum subject at the end of each stage of the relevant level of education (Regulation on the State Requirements for acquisition of professional qualification as "teacher", 11.11.2016).

The provision of physical education in Bulgaria and Albania is overseen by the Ministry of Education and Science. The Ministry of Education and Science is responsible for delivering school physical education. The Ministry accepts and approves the learning programmes for all levels of the educational system in both countries.

Physical Education in both Balkan countries is an obligatory school subject from the $1^{\text {st }}$ grade to the $12^{\text {th }}$ grade of the educational systems.

The time allocation for physical education in primary school in Bulgaria ( $1^{\text {st }}-4^{\text {th }}$ grade) is between $105-140$ minutes per week (in the 1 st and the $2^{\text {nd }}$ grade - two PE lessons per week of 35 minutes each are provided, plus one lesson of 25 minutes for sports activities as module education, or 105 minutes of PE classes in total; in the $3 \mathrm{rd}$ and the $4^{\text {th }}$ grade - 2,5 PE lessons are provided per week of 40 minutes each, plus one 40 minutes' lesson for sports activities as module education, or 140 minutes of $\mathrm{PE}$ classes in total) that is to be delivered by qualified primary school teachers or specialized physical education teachers (www.mon.bg).

The time allocation for physical education in Post-primary school physical education $\left(5^{\text {th }}-12\right.$ th grade) is 120-135 minutes per week (three PE lessons per week of 40 or 45 minutes each are provided) that is to be delivered by qualified physical education teachers. (www.mon.bg)

Law \#69/2012 on Pre-university Education in Albania elaborates some of the most progressive principles in education, including but not limited to "the open and inclusive approach to schooling for children with disabilities, the heightened role of parents in school governance, increased school autonomy, and restructuring the sequence of basic education" (Education Policy Review Albania, 2017).

In Albanian public schools Physical Education is a very important subject. The recent educational reform has changed PE hours from 2/week to 3/ week for all grades of Elementary Education (grade 1 - 5), Lower Secondary Education (grade 6 - 9), and Secondary Education (grade 10 - 12). The field of "Physical Education, Sports and Health” is conducted for 35 weeks of instruction with 3 teaching hours each, a total of 105 hours for each class.

Starting from the school year 2014/2015 in the framework of curricular reform in Albania, new programmes for pre-university education were also developed for the subject of Physical Education. In this reform, Physical Education has undergone changes, not only referring to the load (even in relation to other subjects), but also to the substantive review of the subject (Education Policy Review Albania, 2017).

Physical Education teachers in Bulgaria teaching students from the $5^{\text {th }}$ to the $12^{\text {th }}$ grade and in many schools in the country, from the $1^{\text {st }}$ to the $4^{\text {th }}$ grade, are specialists, who have graduated the National Sports Academy or specialized in Physical Education at the Universities in Veliko Tarnovo, Blagoevgrad, Shumen, Plovdiv and Sofia. The specialty of Physical Education is taught at the National Sports Academy in Sofia, the Faculty of Pedagogy and at the Pedagogical Faculties of the Universities in Bulgaria.

The Bachelor's degree in Physical Education lasts 4 years or 8 semesters and consists of 240 ECTS. The number of credits in different study areas is presented on table 1.

Table 1. Number of credits on the Bachelor's degree in Physical Education at National Sports Academy (Mileva, 2012)

\begin{tabular}{|l|l|}
\hline \multicolumn{1}{|c|}{ MODULES } & \multicolumn{1}{c|}{ ECTS } \\
\hline Sports activities and Methods & 77 ECTS \\
\hline Physical education (theory) and Pedagogy & 17 ECTS \\
\hline Medical and biological sciences & 32 ECTS \\
\hline Social sciences & 29 ECTS \\
\hline School practice & 29 ECTS \\
\hline Elective subject & 27 ECTS \\
\hline
\end{tabular}


Pre-graduate internship on the Bachelor's degree in post-primary level in Bulgaria is realized in the last semester for 6 weeks. During the internship students teach lessons only in physical education. The internship is organized under the guidance of an assistant who keeps in touch with mentor teachers and ends with a State practical examination in PE before a State exam committee (www.mon.bg). During the 6 th and $7^{\text {th }}$ semester students have methodical practice at schools where they attend PE lessons and observe the teaching of physical education teachers.

The duration of Bachelor's study in Physical education in Albania lasts 3 years. The Master's degree is 2 years, and 1 year practicum is obligatory. Three Albanian universities provide pre-service education for future PE teachers. These are the Sports University of Tirana and the Pedagogical Faculties of the Universities in Elbasan and Shkodra. The curricula for PE teachers' training encompasses three basic groups of disciplines: 1) the disciplines in the field of academic education, 2) pedagogical and psychological disciplines (pedagogy, psychology and methods of vocational subjects), 3) teaching practice.

Within the general pedagogy, the contents of general pedagogy, didactics and methodology of pedagogical research are studied. Psychology includes the contents of developmental and pedagogical psychology. This knowledge forms the necessary basis for each teacher to understand and study the method in a more qualitative way. It must be underlined that there are differences in the universities in Albania, concerning the number of teaching hours provided for pedagogical, psychological and methodological disciplines, as well as the subjects including these sciences.

The teachers in PE in Albania in higher grades of primary schools (Five to Eight) must have the diploma of higher education from a relevant university. All teachers must take the professional teacher's examination.

The in-service education in Bulgaria has a compulsory status. "Enhancing qualifications is an ongoing process of refinement and enrichment of pedagogical competencies of teachers to effectively fulfill the requirements of the implemented work and career development" (www.mon.bg). The improvement of the qualification of the pedagogical specialists is carried out by: a) specialized service units, higher schools and scientific organizations;

b) training organizations whose training programmes have been approved by the Ministry of Education and Science and are entered in the information register.

Based on their level of qualification, pedagogical specialists can acquire the following Vocational Qualification Degrees: $5^{\text {th }}, 4^{\text {th }}, 3^{\text {rd }}, 2^{\text {nd }}$ and $1^{\text {st }}$ (www. mon.bg). On this ground, physical education teachers can take a higher position - senior teacher or master teacher.

Some universities in Bulgaria have opened departments for professional development and training of PE teachers. In 2016 a department for continuing professional development of PE teachers was created at The National Sports Academy in Sofia. It was aligned with the new Law for Pre-school and School Education and the new regulations for the professional qualification of teachers.

The laws concerning education in Albania determine the necessity of a permanent in-service training of educational staff in education establishments (Education in the Republic of Albania, 1998). The content of the in-service training programme includes children and developmental psychology; methodology with didactics; teaching methods, pedagogical psychology; methods of pedagogical work; information technologies; application of new teaching technology and scientific fields important for certain subjects; social psychology and other fields.

Universities, professional societies and scientific professional organizations and different NGOs offer programmes of in-service training by scientific-teaching fields and organize their direct realization.

In-service training within the school can be realized as individual or collective training (Education in the Republic of Albania, 1998). The individual type is accomplished by mastering the approved programme, monitoring professional and scientific literature, applying professional and scientific achievements, performing experimental lessons and giving professional lectures, issuing professional papers, as well as by acquiring a higher degree of qualifications. The collective in-service training is realized within the professional teachers work groups and teachers' councils in one or sever- 
al schools in the area of a municipality or region, or within professional societies.

The school principal and inspectors of local education authorities and the Ministry of Education and Science in Albania monitor the realization of the in-service training.

\section{DISCUSSION}

Similarities in the functioning of PETE were found in the two Balkan countries. The educational systems in Albania and Bulgaria were in the process of reforms and approving of new regulations and normative documents. The pre-service teacher education was aligned with the Bologna declaration for higher education.

In both PETE systems, special attention was given to in-service training and the continuing professional development of physical education teachers. Concrete educational standards for in-service teacher training were approved. This processes had a positive influence on the professional competences and adaptability of teachers to the changing social and educational environment.

At the same time, there were differences in the preparation of physical education teachers in both countries on the different levels of preparation and professional qualification. Some specific characteristics of each PETE system could be outlined. The most important were the duration and the structure of the learning plans and learning programmes for the training of physical education teachers.

A future study must be directed to the analysis of curricula content of the Bachelor's and the Master's degree in Bulgaria and Albania and to the comparison of different educational areas and teacher practices.

\section{REFERENCES}

Education in the Republic of Albania (1998), Ministry of Education and Science, Tirana, Albania.

Education Policy Review Albania (2017), UNESCO.

Klincarov, I., Popeska, B., Kovac, M., Mileva, E. and Starc, G. (2017), Comparative study on the state and the status of primary physical education in Macedonia, Slovenia and Bulgaria, in Changes in Childhood and Adolescence: Current Challenges for Physical Education, Proceedings of the 12th FIEP European Congress, 2017, Logos
Verlag, Berlin, pp. 89-90.

Mileva, E. (2012). Evropejski izmereniya na sportnopedagogicheskoto obrazovanie. Sofia, Avangard Prima. (Милева, Е. (2012). Европейски измерения на спортнопедагогическото образование. София, Авангард Прима).

Mileva, E., Klincarov, I., Popeska, B., Kovac, M. and Starc, G. (2017). Tendencies in the development of school physical education in Bulgaria, Macedonia and Slovenia, in International Congress "Applied Sports Sciences", 1-2 December 2017, Sofia, Bulgaria, Proceeding book, NSA Press, Sofia, pp. 359-363.

Zakon za preduchilistnoto i uchilistnoto obrazovanie (Закон за предучилищното и училищното образование), available at: https://lex.bg/bg/laws/ ldoc/2136641509 (accessed at 10 August 2019).

Uchebni programi po fizichesko vaspitanie i sport (Учебни програми по физическо възпитание и спорт), available at: www.mon.bg (accessed 15 August 2019).

Naredba № 12 ot 01.09 .2016 za statuta i profesionalnoto razvitie na uchitelite, direktorite I drugite pedagogicheski spezialisti (Наредба № 12 от 01.09.2016 г. за статута и професионалното развитие на учителите, директорите и другите педагогически специалисти), available at: www.mon.bg (accessed 31 March 2017).

Naredba za dargavnite iziskvaniya za pridobivane na profesionalna kvalifikaziya "Uchitel" (Наредба за Държавните изисквания за придобиване на професионална квалификация „Учител“), available at: www.mon.bg (accessed 31 August 2019).

Naredba № 15 ot 22.07.2019 za statuta i profesionalnoto razvitie na uchitelite, direktorite i drugite pedagogicheski spezialisti (Наредба № 15 от 22.07.2019 г. за статута и професионалното развитие на учителите, директорите и другите педагогически специалисти), available at: www.mon.bg (accessed 31 August 2019).

Corresponding author:

Florian Muca

Ph.D. student at Department of Psychology, Pedagogy and Sociology

National Sports Academy "Vassil Levski” 21 "Acad. Stefan Mladenov" Str., Studentski grad, 1700 Sofia, Bulgaria and Tirana International School E-mail: florian-muca@alb.qsi.org 